\title{
Albumin turbidity reaction of blood serum
}

\author{
By S. Turek \\ From the Central Laboratories (Head S. Turek M. D.) of the Psycliatric Hospital, Prague \\ (Chief: K. Dobisek M. D.), Czechoslowakia
}

(Eingegangen am 14. September 1966)

\begin{abstract}
Turbidity reaction of blood scrum has been developed. The turbidity is formed by serum albumin and comes about when the serum is diluted with Mclıwaine phosphate-citrate buffer in the range of pH 3.9-4.4. It is significantly enhanced by warming the solution. The temperaturc must not exceed the point of coagulation. The reaction is suitable as a screening-test of pathological anomalies of serum proteins, especially of albumin.

Blutserum, verdünnt mit Phosphat-Citratpuffer nach McIlwaine bildet im Bcrcich von pH 3,9-4,4 cine Trübung. Die Bildung der Trübung wird durch Erwärmen der Lösung auf eine Temperatur, welche noch nicht zur Denaturierung und Ausfällung des Serumeiweißes führt, beachtlich beschleunigt und ihre Intensität erhöht. Es wurde festgestellt, daß diese 'Trübung von Serumalbumin, welches unter den beschriebenen Bedingungen molekularen Veränderungen mit nachfolgenden Dispersionsveränderungen unterliegt, gebildet wird. Die Intensität der Trübung bei dieser Reaktion hängt von den quantitativen und qualitativen Verhältnissen des Serumaltumins und auch der Globuline des Blutserums ab. Diese Albumintrübungsreaktion des Blutserums kann mit Erfolg in der ḳlinischen Diagnostik als einfacher, schneller und empfindlicher Test der pathologischen Abweichungen von Serumeiweißkörpern verwendet werden.
\end{abstract}

Blood serum, diluted with 0,1 $\mathrm{M}$ phosphate-citrate buffer according to McIlwaINE, has been observed to cause turbidities in the range of $\mathrm{pH} 3,9-4,4$. The onset of the turbidities is considerably accelerated and its intensity increased when the solution is brought up to a temperature which, however, does not cause its drastic denaturation and precipitacion of the serum proteins. The turbidity has been found to be formed by the serum albumin which is, under the described conditions, subject to molecular changes with following changes of dispersity. This finding is in accordance with AOKI and Foster (1), Foster et al. (2) and Petersen and Foster (3). This phenomen on has been employed to create the albumin tu rbidity reaction of the blood serum, applicable in clinical diagnostics.

\section{Method}

$0.2 \mathrm{~m} l$ of blood serum was added to $3 \mathrm{~m} l$ of McILwarNe phosphatecitrate buffer ( $\mathrm{pH} 4.10)$ in a small tcst-tube, the content mixed and the corked test-tube stood in a $50^{\circ}$ water-bath for 30 minutes. Thereafter the test-tube was cooled down to the room temperature, by means of water again. The intensity of the resulting turbidity was measured employing a Pulfrich Zeiss photometer against water, using the red S 66 filter and planparallel absorption cells of 1 or $0.5 \mathrm{~cm}$ thickness. The read absorbance figures were the basis for the following MACLAGAN units which were received according to the calibration on a standard barium sulphate suspension (4).

The aforementioned method has been employed in the total of 1110 blood serum samples of patients and employees of our Psychiatric Hospital. The results were compared with the data obtained from further laboratory examinations and clinical diagnoses, and the following biochemical and clinical correlations of the albumin turbidity reaction were found.

\section{Results}

The intensity of the turbidity depends from the qualitative and quantitative relations of the serum proteins, albumin being the most important. In cases of pathologically low levels of serum albumin the figure of albumin turbidity reaction was always markedly low, however the qualitative changes of albumin also make themselves felt.
The relation of the intensity of the reaction to the globulines of the serum is adverse - an addition of globulines to the solution suppressed turbidity, and also when the figures of reaction were markedly low a simultaneous increase in the globuline fractions of the serum was observed. The fact itself which of the globuline fractions were increased was of no significance. The intensity of the reaction was not influenced in cases of higher bilirubin levcls in the serum. On the other hand, the clinical examination revealed that low values of the albumin turbidity reaction - under 7 units - were always the sign of a pathologic state. Such low values were observed in all cases accompanied by hypoalbuminemia, whether there was a simultaneous absolute increase in globulines or not.

The low figures of the albumin turbidity reaction proved useful in cases of chronic liver lesions, as these values were of a more sensitive and significant character than those of Takata reaction (5). Positive values of the albumin turbidity reaction - low turbidity figures were observed also in a number of inflammatory lesions, tuberculosis, malignant tumours, kidney diseases, nutritional defects, losses of blood proteins, toxemias of pregnancy and in cases of advanced arteriosclerosis.

The physiological range of the albumin turbidity reaction is relatively broad. The upper physiological limit is, however, no real conception, as very high values of turbidity have been noticed in healthy as well as pathologicaly affected people. These high turbidity values - about 50 units - were observed in healthy young adults who showed high levels of the serum albumin over $5 \mathrm{~g} \%$. Nevertheless, the same high values were also observed in two groups of pathological cases. The first group were patients with obstructed gall ducts, including those with transitory obstruction and a slight increase in the bilirubin values. The second group showing very high reaction values were intoxications of overdoses of phenothiazin ataractics. The increased turbidity in both mentioned groups was however not caused by the albumin itself but by the materials released from their 
Tab. 1

Characteristic Cases of the Albumin Turbidity Reaction

The table presents cases of the lowest, mean and highest observed values of the reaction in correlation to the serum protein levels and some turbidity reactions findings of blood serum

\begin{tabular}{|c|c|c|c|c|c|c|c|c|}
\hline Case No. & Sex, Age, Diagnosis & ATR & T. P. & S. A. & A/G & Gr & $\mathrm{Ku}$ & $\mathrm{Ta}$ \\
\hline $\begin{array}{l}1 \\
2 \\
3 \\
4 \\
5 \\
6 \\
7 \\
8\end{array}$ & 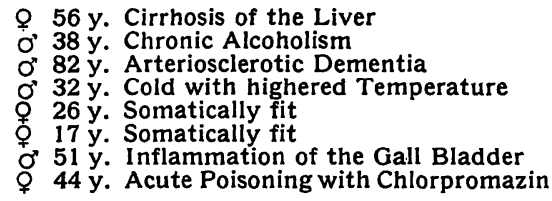 & $\begin{array}{r}0,9 \\
1,6 \\
1,8 \\
10,0 \\
21,6 \\
50,0 \\
\text { over } 50,0 \\
\text { over } 50,0\end{array}$ & $\begin{array}{l}6,80 \\
7,15 \\
4,64 \\
6,75 \\
7,60 \\
7,75 \\
7,60 \\
7,72\end{array}$ & $\begin{array}{l}2,40 \\
2,97 \\
1,85 \\
4,25 \\
4,40 \\
5,20 \\
3,70 \\
4,01\end{array}$ & $\begin{array}{l}0,55 \\
0,71 \\
0,66 \\
1,70 \\
1,37 \\
2,04 \\
0,95 \\
1,08\end{array}$ & $\begin{array}{r}1,9 \\
6,1 \\
13,8 \\
7,9 \\
5,5 \\
2,9 \\
9,6 \\
4,1\end{array}$ & $\begin{array}{r}16,2 \\
5,0 \\
2,2 \\
3,4 \\
4,6 \\
4,0 \\
6,7 \\
5,2\end{array}$ & $\begin{array}{l}++ \\
= \\
E\end{array}$ \\
\hline
\end{tabular}

Abbreviations

ATR: Albumin Turbidity Reaction (in MACLAGAN turbidity units)

T.P.: Total Serum Proteins (in $\mathrm{g} / 100 \mathrm{ml}$ )

S. A.: Serum Albumin (in $\mathrm{g} / 100 \mathrm{ml}$ )

A/G: Albumin/Globuline Quotient

Gr: GREENSPAN Test ("Acid Precipitable Globuline") in MACLAGAN turbidity. unit

Ku: Zincsulphate Test of KUNKEL (in MACLAGAN turbidity units)

Ta: Takata Reaction

albumin binding - by phenothiazin compounds in cases of ataracties intoxication and by fatty acids in cases of the gall ducts obstruction. Very high values of the albumin turbidity reaction must be therefore always evaluated taking into consideration the serum albumin level findings, further the laboratory findings of the gall ducts obstruction and the results of the toxicologic examination. On the other hand, low values of the albumin turbidity reaction uniformly show the presence of a pathologic condition. This is why the method described in this paper, is owing to its simplicity and quick employment possibilities, a suitable screeningtest of pathologic anomalies of the serum albumin, hypoalbuminemia, and of the lowered albumin/globuline quotient as well.

Typical cases of findings of the albumin turbidity reaction in relation to other indices are seen in table 1 .

\title{
References
}

1. Aokr, K. and J. F. Foster, J. Am. Chem. Soc. 78, 3538 (1956). - 2. Foster, J. F., M. Sogami, H. A. Petersen and W. J. Leonard jR., J. Biol. Chem. 240, 2495 (1965). - 3. PeterSEN, H. A. and J. F. Foster, J. Biol. Chem. 240, 2503; 3858 (1965). - 4. Shank, R. E. and C. L. Hoagland, J. Biol. Chem.
162, 133 (1946). - 5. Arbeitsvorschriften für das Pulfrich-Photometer, Sammlung I, Carl Zeiss, Jena, Gustav Fischer Verlag, Jena 1959, p. 183. - 6. Greenspan, E. M., J. Mt. Sinai Hosp., 21, 270 (1955). - 7. Kunked, H. G., E. H. Ahrens and N. J. EISENMENGER, Gastroenterology 11, 499 (1948).

Dr. St. Turek

Prag 4/CSSR, Olbrachtova 1057

\section{Untersuchung von Harnsteinen mit Hilfe eines neuen analytischen Verfahrens}

\author{
Von G. LIPTAY und M. BERENYI
}

\begin{abstract}
Aus dem Institut für Allgemeine Chemie der Tecbnischen Universität Budapest (Direktor: Prof. Dr. L. Erdey) und der Urologischen Klinik der Universität für Medizinische Wissenschaften Budapest (Direktor: Prof. Dr. A. Babics)
\end{abstract}

(Eingegangen am 2. November 1966)

Es wird ein neues komplexes, thermoanalytisches Instrument, der Derivatograph, zur Prüfung von Nierensteinen vorgeschlagen. Die meisten Komponenten der Steine erleiden bei steigender Temperatur verschiedene physikalische und chemische Änderungen. Aus der Temperatur bei der diese Änderungen auftreten bzw. aus dem Maß der Gewichtsänderung kann die Art und Menge der betreffenden Komponenten gefolgert werden. Die Methode ist sowohl für Forschungszwecke, wie für Routineuntersuchungen geeignet.

A new complex thermoanalytical instrument, the derivatograph, is proposed for testing kidney stones. Most components of the stones undergo various physical and chemical changes with increasing temperature. The type and quantity of the constituents can be determined from the temperature at which these changes occur and from the change in weight. The method is suitable for both research and routine investigations.

Die sog. Thermoanalyse zeigt gewisse vorteilhafte Eigenschaften bei ihrer Anwendung in der klinischen Analyse. Zur Bestimmung der Zusammensetzung von Harnsteinen kann man sich vielerlei analytischer Methoden bedienen. Wir benutzten zur Bestimmung der kristallinen Komponenten ein neues, an der Technischen Universität Budapest konstruiertes komplexes thermoanalytisches Gerät, den sog. Derivatographen. Die Thermoanalyse untersucht die auf Einwirkung von Temperaturänderungen in den verschiedenen Stoffen verlaufenden Vorgänge. Die meisten Substanzen, darunter die Nierensteine erfahren bei gleichmäßig steigender Temperatur verschiedene physikalische und chemische Änderungen, aus denen man die qualitative und quantitative Zusammensetzung der Komponenten der betreffenden Substanz folgern kann. Der Derivatograph nach F. PAúlik, J. PAulik und L. ERDEy registriert als Funktion der Temperatur der Probe die Crewichtsänderungen (TG-Kurve), die Geschwindigkeit der Gewichtsänderung (DTG-Kurve), weiterhin die Enthalpieänderung (DTA-differential thermoanalytische Kurve) der zu prüfenden Substanz. 